\title{
Study Secondary Purpose
}

National Cancer Institute

\section{Source}

National Cancer Institute. Study Secondary Purpose. NCI Thesaurus. Code C147142.

The ancillary reason or intention for the execution of an interventional or noninterventional clinical study. 